\title{
A MODEL FOR DEVELOPING HIGH-QUALITY ONLINE COURSES: INTEGRATING A SYSTEMS APPROACH WITH LEARNING THEORY
}

\author{
Maria Puzziferro \\ Colorado State University-Global Campus
}

Kaye Shelton

Dallas Baptist University

\begin{abstract}
As the demand for online education continues to increase, institutions are faced with developing process models for efficient, high-quality online course development. This paper describes a systems, team-based, approach that centers on an online instructional design theory (Active Mastery Learning) implemented at Colorado State University-Global Campus. CSU-Global Campus is a newly-created online campus within the Colorado State University System, and launches in Fall 2008 with fully-online undergraduate degree completion programs and Master's degrees.
\end{abstract}

\section{KEYWORDS}

Online Course Development, Instructional Design, Online Faculty Development

\section{INTRODUCTION AND OVERVIEW}

Developing or creating an online course is a highly complex and multifaceted process. There are several levels of "development" that need to occur, and no one person is likely capable of discharging all of the expertise levels and roles inherent in the process. In order to meet the growing demand for quality online education, a course development model that provides a common framework for consistency, design, pedagogy and content can be very effective.

The notion of collaborative course development is well-described in the literature, in the context of team dynamics, instructional design, and course quality $[1,2,3,4,5]$. Institutions such as Park University, which employs a standardized online course development model incorporating collaborative efforts among faculty and instructional design staff, have reported positive results [6]. The model presented in this paper also uses an integrated, collaborative model for development, but is aligned with Active Mastery Learning, an instructional development theory being refined and tested at CSU-Global Campus.

We begin from the assumption that collaboration provides an optimal environment for developing rich, dynamic, and interactive online courses. In addition, we acknowledge the need for a sustainable "business model" for online course development that offers a scalable production process that is the foundation for quality, efficiency, and productivity for the entire institution. However, online courses are not widgets; rather, they are learning experiences, and so the proposed model incorporates learning benchmarks and best practices for online pedagogy, conceptually aligned with Bloom's Taxonomy and practical implementation of Quality Matters criteria [7]. Creating the team culture, defining the learning vision and 
framework, identifying the resources, and crafting the production workflow for effective teamwork are all critical planning elements for administrative leadership.

Worth noting is that the degree of collaboration described in this model does require significant institutional commitment in terms of resources, staff, technological tools, and overall effort. However, institutions can adapt this model in multiple ways; for example by appropriately scaling the size of teams, the use of part-time staff or dual roles to fulfill specific team roles, or allowing longer course production times.

This paper will examine the collaborative online course development process from an administrative perspective, and present a systemized approach to developing, implementing and managing high-quality, streamlined online course production.

\section{THE BUSINESS MODEL}

Online course production does not occur in a vacuum. The system, processes, and workflow are driven by the "business functions" of the institution, which include consideration of the research, the market demand, the market expectations, and the course distribution plan - and building in the flexibility to adapt to market, technology, and fluctuations. As Greenberg [8] powerfully points out, universities are indeed businesses, and if they are to compete in the ever-growing competitive online higher education market, they need to take a hard look at their culture and practices. This must occur at all levels, and most importantly, in the instructional realm, where semesters are no longer 16 weeks, faculty are no longer the only "experts," and the classroom is no longer time and place-bound.

In order to compete in the online higher education market, quite simply, institutions need to get relevant, high-quality product to market quickly. It is no longer feasible to have 18-24 months course production time, and to leave the format, navigation, and look and feel of the final course product to the discretion of each individual course developer. In a market where students expect fast service, consistency, and quality, a more streamlined production approach is now required.

High-quality online course development and delivery are essential goals to the fundamental mission of CSU-Global Campus. As such, the investment in quality, faculty support, and instructional development staffing enable the model described in this paper. The most recent Sloan-C report indicates that approximately three-quarters of respondents from public instructions reported that online education is critical to the long-term strategy of their institutions [9]. The integration of online education into the institutional strategic planning and goal-setting process is critical to achieving the level of quality needed to complete in the competitive industry of online education.

It is also important to emphasize that course developers are customers, too - and this is has become a competitive market. In a market where there are abundant job opportunities for online course developers and faculty, institutions must retain the best workforce to be become and remain competitive while providing quality online course materials. Faculty and other subject matter experts (SMEs) have high expectations about the process, support, expectations, and workload involved in online course production.

The online course production process must take into account the distribution plan; in other words, to whom and where will the courses be distributed? Courses are being developed for delivery to a global audience, and quite possibly, in high volume. Even institutions that are tentatively venturing into the 
online realm, building a process that can handle volume will save time and effort later and support scalability.

The course production framework must also be flexible enough to adapt to changes in technology, student and faculty evolving expectations, new research in the field of online pedagogy, and curricular changes. For this reason, we recommend a concurrent course revision and maintenance framework that constantly compels the production team to quantitatively and qualitatively assess the efficiency of the framework, and maintain the flexibility to make adjustments as needed.

In sum, the business model of course production is a framework, but should be flexible and dynamic.

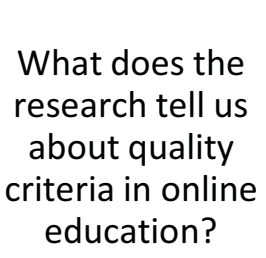

What is the process for course maintenance and revision?

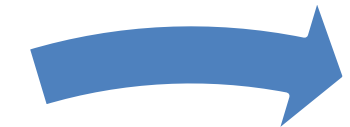

Who is the market and what do they want?

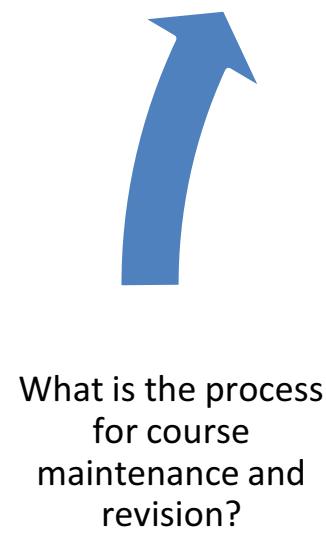

$\checkmark$

What are the most current technologies, and how can they support learning?

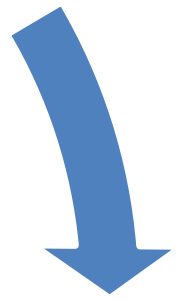

What is the course delivery/distribution plan and how does the production framework support that plan?

Figure 1: Online Course Production Framework: Guiding Questions

\section{DEVELOPING THE QUALITY VISION AND COURSE DESIGN STANDARD}

It would be naïve to propose a production process such as this without considering the political and cultural context of higher education. Academic freedom and faculty governance structures create a 
cultural framework that necessitates some adjustment of the processes outlined in this paper. However, all can likely agree that academic quality is still at the heart of what we do. And, one of the primary jobs of the online education administrator is to develop a working relationship with faculty based on a mutual recognition and respect for the not necessarily mutually exclusive guiding principles of course consistency and academic freedom.

At the very core of "quality" is the principle that pedagogy must be the driver of the production process, not technology. Although technology is certainly an important consideration, it should always support the learning goals and objectives at both the program and course levels. There is general agreement of this principle in the literature $[1,2,10]$; however, in practice the technology can often be very alluring to creative and innovative instructional development teams--but technological bells and whistles will not replace good pedagogy. Figure 1 outlines the guiding questions for the process as a whole.

Before the production framework and process can begin, it is critical to have a vision of quality and a course design standard derived from this vision. The standard must be documented in such a way as to clearly communicate to the course production team the design expectations and the specifications for the deliverables. Documentation can include a sample course, a spreadsheet of course elements, and/or a rubric. Often, we get bogged down in rubrics, technical specifications, and checklists and lose the "vision" for quality. To help the team stay focused on that vision, we recommend having a quality vision statement that is used to guide the team, such as the one below:

Quality online courses are well-organized into learning units; have clear learning goals and objectives; include materials and activities that directly support the learning goals and objectives; engage the learner through interaction with content, other students and the instructor; and offer rich and relevant resources for students. Most of all, online courses should be fun, engaging, pedagogically sound, and relevant.

The vision statement should be grounded in theory, and clearly defined in an operational, as well as conceptual way. Our learning model is Active Mastery Learning, which begins from the assumption that the course to be developed is not just flat, one-dimensional "content" - it is a series of learning environments and activities. Effective learning motivates learners, engages them through communication with each other and the instructor, develops their skills, and enables learners to transfer their new skills to other settings. The classic Seven Principles of Good Practice, adapted to technology illustrate the principles of quality in education [11]:

1. Good Practice Encourages Contact Between Students and Faculty

2. Good Practice Develops Reciprocity and Cooperation Among Students

3. Good Practice Uses Active Learning Techniques

4. Good Practice Gives Prompt Feedback

5. Good Practice Emphasizes Time on Task

6. Good Practice Communicates High Expectations

7. Good Practice Respects Diverse Talents and Ways of Learning

Virtually all educators agree that the Seven Principles of Good Practice represent an excellent starting framework for developing a vision of quality. We begin the Active Mastery Learning foundation here also, and emphasize the guiding belief that all students can learn when the learning environment is active 
and authentic. Learners must be engaged in the experience, not just the exercise, of learning.

Thus, authentic learning is an important part of the vision of quality for the course, and emphasizes the importance of creating course activities that actively engage students in exploring, discussing and analyzing abstract concepts in real-world, relevant contexts [12]. Lombardi [13] provides an excellent overview of authentic learning, its importance to today's students, and examples of specific exercises and strategies for building authentic learning into online course environments. These activities include simulations, student-created media, inquiry-based learning, and peer-based evaluation.

We believe that constructivist, active and authentic activities are most effective, and the general agreement in online education is that "active" and community-based virtual environments are the most favorable for both student satisfaction and learning outcomes. However, students must also master content in order to meet certain competencies.

Bloom's taxonomy explains learning as a progression from simple learning to the higher levels of critical thinking, as illustrated in Figure 2 [14]. Mastery learning can be conceived of as an instructional philosophy - at the core is the belief that all students can learn, if given the time and opportunity. Not all students move up the ladder of Bloom's Taxonomy at the same pace, but the core belief is that they can. Mastery learning also does not focus on the content, but focuses on the process of mastering the specific learning objectives tied to the content.

However, mastery learning is just one piece of the puzzle. In a recent study of the effectiveness of mastery learning, Kazu, et al. [15] found that mastery learning increased student achievement, but that without activities that encouraged participation, students grew bored and thus achievement was lowered. The pedagogical philosophy at CSU-Global Campus is that skills and competencies are just one part of the learning process. Mastery learning activities that are competency-based provide content mastery opportunities and immediate feedback, and account for a nominal portion of each course grade. Students need to become competent in specific skills and topical areas, but then they move on to exercise higherlevel skills such as critical-thinking, peer collaboration, synthesis, evaluation and new knowledge construction-which all account for 90 percent or more of the course grade in various projects, assignments and portfolio-quality work. In a global, competitive world, these higher-order skills may give students the edge over their peers who just have "skills," and equip them with the proficiencies to be effective leaders and managers in their field. 


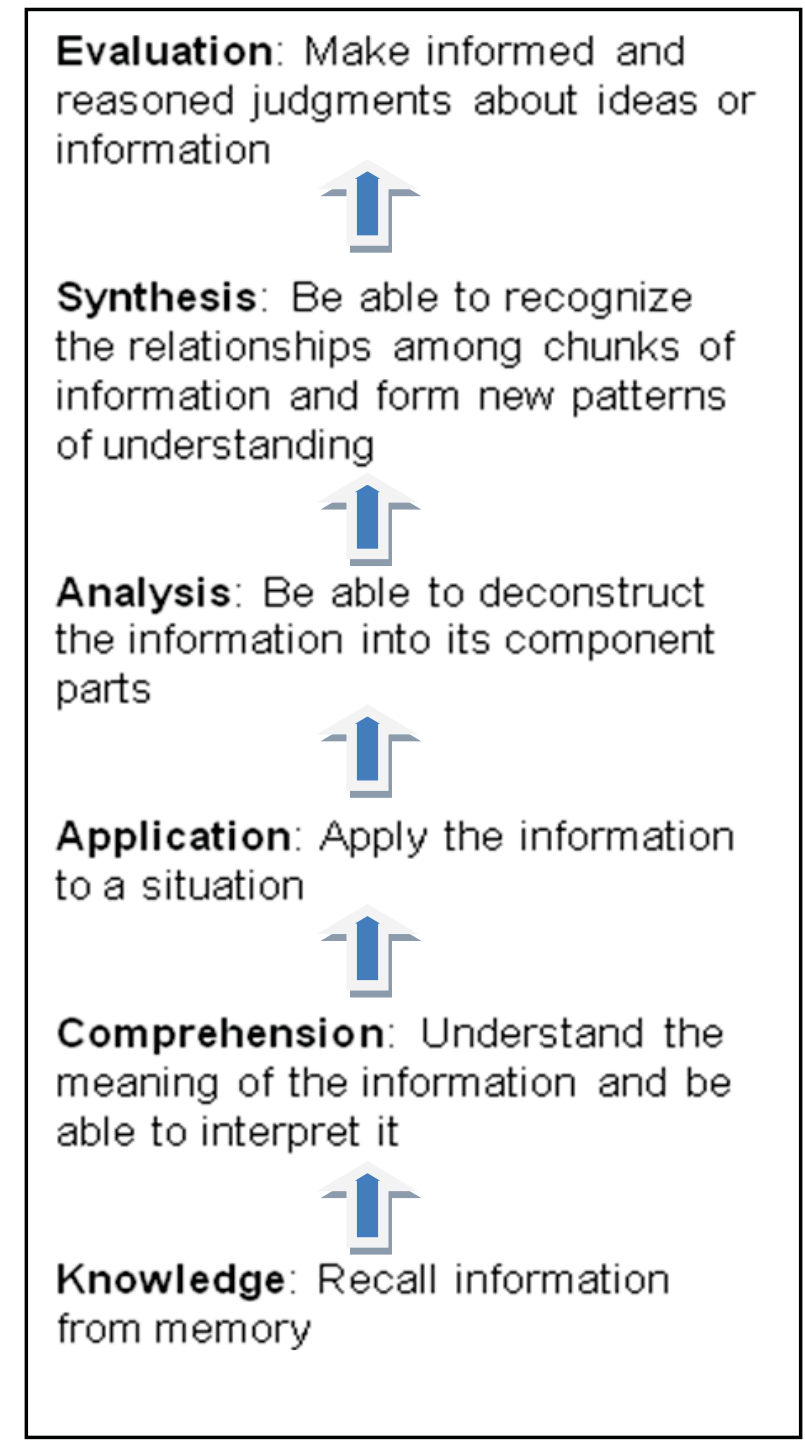

Figure 2: Levels of Learning, Based on Bloom's Taxonomy

Derived from Bloom's taxonomy [14], students learn by:

a) mastering information, such as key concepts, terms and ideas through exposure to the information and recall,

b) progressively grasping the information by practicing learning activities that focus on recall, trialand-error, and building the vocabulary and comprehension of the information,

c) applying the information to a problem-based situation that can be collaborative,

d) analyzing the problem further by deconstructing the information and reconstructing it into a solution,

e) by applying and analyzing the information, begin to recognize the patterns or relationships between the information and the problem,

f) creating new knowledge and the ability to reason about the information and apply it practically to situations.

Thus, as illustrated in Figure 3, our online learning model utilizes instructivist techniques, such as 
mastery learning, to guide students to fully grasp terms/concepts (content), and then employs constructivist techniques to engage students to apply the information in collaborative contexts. The expectation is that all learning activities foster the highest degree of instructor-student, student-content, and student-student interaction, with consideration of the particular discipline and course objectives.

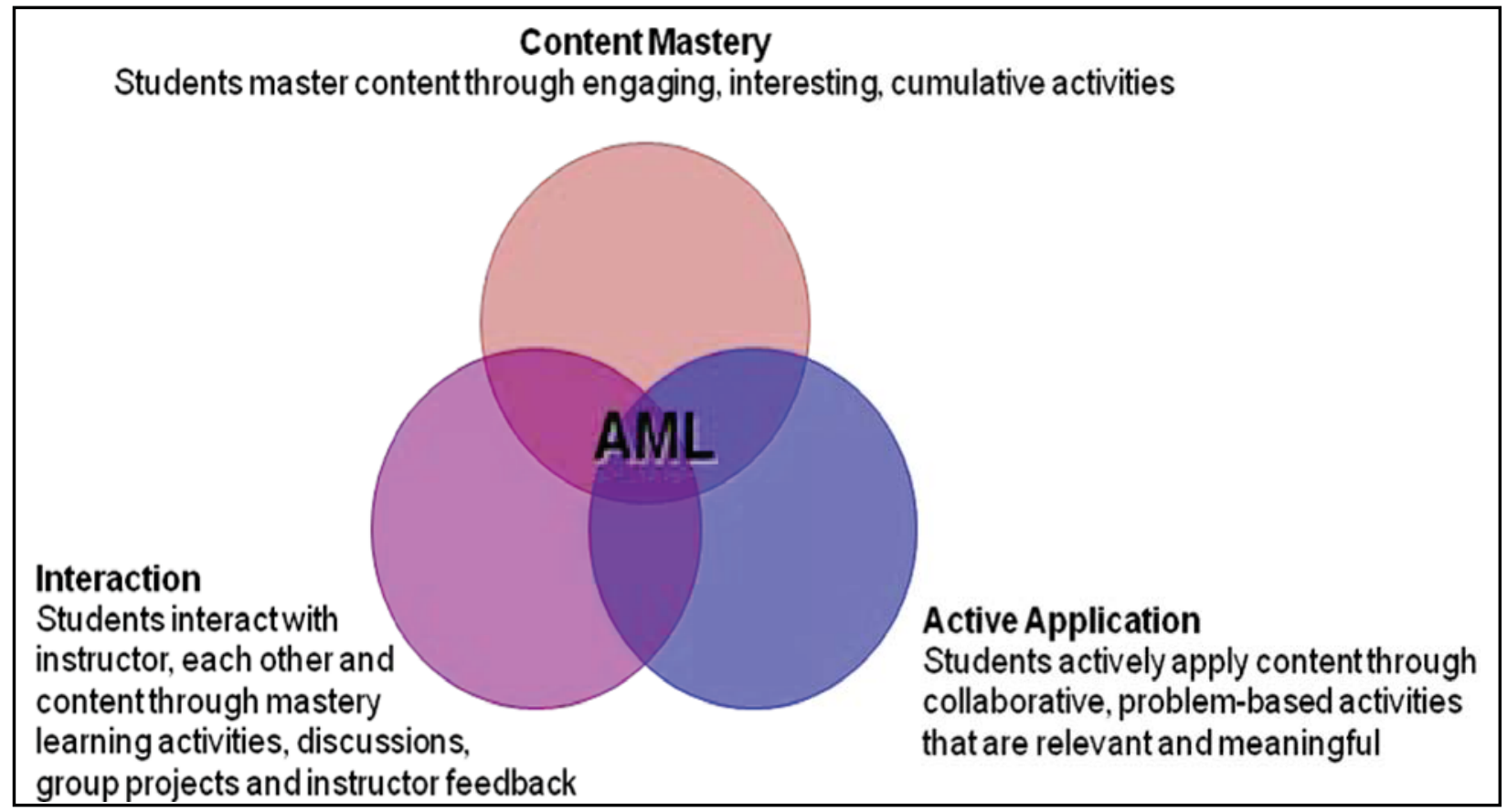

Figure 3: Active Mastery Learning Model

The measurement of quality is a complex and sometimes nebulous task. The Quality Matters program [7] is a research-based program that has received national recognition for their research-based rubric and inter-institutional peer-review processes (www.qualitymatters.org). The Quality Matters rubric is an excellent guide for creating a design standard, or an evaluation system, and can be customized and adapted as needed. We have adapted the rubric to convey the online course design elements to support Active Mastery Learning, and the specific quality criteria within each element.

\section{THE COURSE DEVELOPMENT PROCESS: DEFINING THE TEAM ROLES}

While in the early stages of online education, instructors created their own course materials with little instructional design support; however, tales of frustration and lack of support rang in the halls of Academe. Faculty are experts in their discipline, having studied and researched extensively; they cannot be expected to become instructional design experts in the amount of time provided for course development. Designing an online course requires a systemic process that dissects the course learning objectives, presents content, interactivity, and assessment.

One overarching goal of this course development model is to provide ample instructional design, media development, and other resources and support. As Oblinger and Hawkins [16] point out, online courses are no longer content-driven; rather they are complex, technologically-mediated learning experiences that require high-level instructional design, multimedia expertise, and technology skills that few faculty 
possess. Courses designed under this model reflect the innovative and creative intent of the faculty content expert, while the instructional design team ensures that each course is Section 508 compliant, accurate, error-free, tested for usability and incorporates an appropriate balance of content mastery activities, interactive activities to foster peer engagement, critical thinking assignments, and high-level synthesis projects.

\section{A. Team and Systems Approach to Online Course Development}

Moore and Kearsley [17] in describing the systemic model of distance education, compared it to the system of the human body. Each part of the body plays an integral part in how the body works as a whole, some are more important than others, but it takes all parts to support a successful system. The same could be said for the online course development process which is heavily interrelated to online course delivery and is a subsystem of the overall distance education system. Peters [18] recognized early on that the system for distance education was similar to that of the industrialization process because it requires "careful prior planning on a division of labor basis, costly development, and objectivization through media" (12, p. 112). While Peters saw this as a comprehensive system for the production of goods relevant to distance education, the model still applies to the development and scalability of online courses. Peters' [19] theory focuses on the division of labor for the process and concludes the following rationales:

- The development of distance study courses is just as important as the preparatory work taking place prior to the production process.

- The effectiveness of the teaching process is particularly dependent on planning and organization.

- Courses must be formalized and expectations from students standardized.

- The teaching process is largely objectified.

- The functions of academics teaching at a distance have changed considerably vis-a-vis university teachers in conventional teaching.

- Distance study can only be economical with a concentration of the available resources and a centralized administration. (p. 110)

There is a body of recent literature that supports the notion of team-based online course production. Xu and Morris [14] studied team roles and curricular decisions of a course development team, consisting of a project coordinator, a web instructional designer, and four faculty members. They found that despite some issues arising from the collaborative process, such as increased workload and conflicting opinions on course materials, the faculty members considered the experience highly positive.

In our model, we recommend a single faculty member working with the instructional development support team to minimize the potential academic conflict, and also recommend a stronger leadership role for the Instructional Technologist. Hawkes and Coldeway [4] caution against the "lone ranger" approach, where faculty are the graphic artist, the web page designer, the instructional designer, and even the programmer. However, in our model, faculty unequivocally drive the subject matter and work closely with the instructional technologist on pedagogical decisions, and are solidly supported by the instructional development team in matters of technology and programming. An important theme in the literature is that faculty do not resist technology or online course pedagogy when provided with resources and support [5]. The support investment is well worth it to create efficient processes where all team members are utilizing their specific talents and expertise, and where all team members feel supported.

We suggest the following roles for a team approach to online course production: 


\begin{tabular}{|c|c|}
\hline Team Member & Role \\
\hline Course Developer & $\begin{array}{l}\text { - Senior subject matter expert/lead faculty member } \\
\text { - Ensures that the development is in line with the curricular } \\
\text { goals and ensures academic quality exists }\end{array}$ \\
\hline Course Development Team Member & $\begin{array}{l}\text { - Also a subject matter expert } \\
\text { - One or more may participate, depending upon scope of } \\
\text { project, or other special circumstances } \\
\text { - Works collaboratively with the lead Faculty developer to } \\
\text { select and/or design course materials, etc. }\end{array}$ \\
\hline Instructional Technologist & $\begin{array}{l}\text { - Acts as a pedagogical and design consultant on up to } 10 \\
\text { concurrent development projects } \\
\text { - Employs an instructional design model, such as ADDIE } \\
\text { - Act } \\
\text { - Assists the team in selecting course materials and learning } \\
\text { objects that support online pedagogy } \\
\text { - Ensures that the course design is adhering to the quality } \\
\text { vision and design standard }\end{array}$ \\
\hline Course Technicians (Techs) & $\begin{array}{l}\text { - Acts as technical support on several concurrent } \\
\text { development projects } \\
\text { - Provide programming support and assistance with } \\
\text { technical aspects of the course; for example, load course } \\
\text { content, design course banner and graphics, work on look } \\
\text { and feel of course, find or create learning objects, load } \\
\text { quiz and exam questions into the CMS, help developers } \\
\text { record audio/video, help developers ensure that the } \\
\text { technologies are appropriate for the course, include text } \\
\text { scripts for ADA compliance, test the course links, } \\
\text { proofread, etc. }\end{array}$ \\
\hline $\begin{array}{l}\text { Librarian / Copyright Clearance } \\
\text { Coordinator }\end{array}$ & $\begin{array}{l}\text { - Provided through library services for review of courses for } \\
\text { TEACH Act compliance and to handle copyright } \\
\text { clearance, reserve readings, etc. }\end{array}$ \\
\hline
\end{tabular}

In the organizational model being established at Colorado State University-Global Campus, the Instructional Development Unit houses the above team members, and also includes supplementary roles, including a Director of Faculty Development and Support, a Director of Institutional Effectiveness and Quality Assurance, Program Chairs, and Core Faculty. Together, the Instructional Development team supports the entire online course development model and integrates faculty into the organization as key players and decision makers, not just clients.

\section{Who Does What?}

The table below illustrates the content elements of an online course, derived from Active Mastery 
Learning and the Quality Matters rubric [7], and denotes the team member with primary responsibility for each online course element.

\begin{tabular}{|c|c|c|c|}
\hline $\begin{array}{l}\text { Course } \\
\text { Element }\end{array}$ & Standards & Roles & Examples \\
\hline $\begin{array}{l}\text { Course } \\
\text { Overview and } \\
\text { Introduction / } \\
\text { Student } \\
\text { Orientation }\end{array}$ & $\begin{array}{l}\text { - Introduction to the course } \\
\text { structure, style, learning } \\
\text { experience, technology } \\
\text { requirements } \\
\text { - Explanation of support } \\
\text { resources } \\
\text { - Explanation of course } \\
\text { policies } \\
\text { - Navigational instructions } \\
\text { - Explanation of general } \\
\text { expectations } \\
\text { - Instructor introduction }\end{array}$ & $\begin{array}{l}\text { - Course Developer and } \\
\text { Instructional } \\
\text { Technologist } \\
\text { - Instructional } \\
\text { Technologist to provide } \\
\text { any static institutional } \\
\text { information (such as } \\
\text { support resources, } \\
\text { contact information, } \\
\text { institutional policies, } \\
\text { etc.) }\end{array}$ & $\begin{array}{l}\text { - Welcome video } \\
\text { - "Icebreaker" activities } \\
\text { - Text announcement } \\
\text { - Any"housekeeping } \\
\text { items" covered }\end{array}$ \\
\hline Syllabus & $\begin{array}{l}\text { Detailed syllabus document, } \\
\text { with timelines, course } \\
\text { policies, unit schedules, and } \\
\text { other specification included } \\
\text { in a template provided to } \\
\text { faculty }\end{array}$ & $\begin{array}{l}\text { - Instructional } \\
\text { Technologist to provide } \\
\text { template } \\
\text { - Course Developer } \\
\text { modifies course- } \\
\text { specific information }\end{array}$ & \\
\hline $\begin{array}{l}\text { Course } \\
\text { Curriculum/ } \\
\text { Objectives and } \\
\text { Learning } \\
\text { Outcomes }\end{array}$ & $\begin{array}{l}\text { - Course topics are clearly } \\
\text { explicated } \\
\text { - Course level learning goals } \\
\text { and objectives clearly stated } \\
\text { and address content mastery, } \\
\text { critical thinking skills, and } \\
\text { core learning skills } \\
\text { - Course outcomes are clear } \\
\text { and measurable } \\
\text { - Each module and unit } \\
\text { includes this element }\end{array}$ & $\begin{array}{l}\text { - Course Developer } \\
\text { - Instructional } \\
\text { Technologist }\end{array}$ & $\begin{array}{l}\text { - List of clear objectives } \\
\text { and learning outcomes } \\
\text { - Identification of } \\
\text { knowledge needed in } \\
\text { subject area to gain } \\
\text { expertise }\end{array}$ \\
\hline Course Content & $\begin{array}{l}\text { - The course materials support } \\
\text { the learning goals and } \\
\text { objectives } \\
\text { - The course materials appeal } \\
\text { to diverse learning styles and } \\
\text { are appropriate to the online } \\
\text { learning environment } \\
\text { - The course materials are } \\
\text { well-organized into a logical } \\
\text { flow, and easily accessible } \\
\text { - All course materials are } \\
\text { appropriately cited and } \\
\text { copyright compliant }\end{array}$ & $\begin{array}{l}\text { - Course Developer } \\
\text { - Instructional } \\
\text { Technologist and } \\
\text { Course Technician (to } \\
\text { help select types and } \\
\text { formats of content) } \\
\text { - Librarian }\end{array}$ & $\begin{array}{l}\text { - Textbook readings, } \\
\text { audio clips, video clips, } \\
\text { lecture notes, podcasts } \\
\text { - Slideshows } \\
\text { - Worksheets for lecture } \\
\text { support }\end{array}$ \\
\hline Mastery & - Activities are included that & - Course Developer & - Flash-based learning \\
\hline
\end{tabular}


A Model for Developing High-Quality Online Courses: Integrating a Systems Approach with Learning Theory

\begin{tabular}{|c|c|c|c|}
\hline Activities & $\begin{array}{l}\text { allow students to practice } \\
\text { applying the informational } \\
\text { concepts presented in the } \\
\text { course content } \\
\text { - Activities are non- } \\
\text { threatening, and are } \\
\text { engaging, interesting, and } \\
\text { even entertaining } \\
\text { - Activities allow for multiple } \\
\text { attempts } \\
\text { - Activities are based on } \\
\text { course materials that are tied } \\
\text { directly to learning } \\
\text { objectives } \\
\text { - Activities provide specific, } \\
\text { immediate feedback and } \\
\text { students are able to track } \\
\text { their progress }\end{array}$ & $\begin{array}{l}\text { - Course Technician (to } \\
\text { help select types and } \\
\text { formats of content, or } \\
\text { create/load activities) } \\
\text { - Librarian (when } \\
\text { necessary, to clear } \\
\text { copyright for learning } \\
\text { objects) }\end{array}$ & $\begin{array}{l}\text { exercises such as games } \\
\text { like Jeopardy, } \\
\text { crossword puzzles, and } \\
\text { digital flashcards } \\
\text { - Online quizzes } \\
\text { - Simulations }\end{array}$ \\
\hline $\begin{array}{l}\text { Interaction and } \\
\text { Collaboration }\end{array}$ & $\begin{array}{l}\text { - Interactive activities promote } \\
\text { interaction among student, } \\
\text { and with instructor } \\
\text { - Interactive activities are tied } \\
\text { directly to learning } \\
\text { objectives } \\
\text { - Interactive activities engage } \\
\text { students with the application } \\
\text { of the information in a } \\
\text { meaningful and interactive } \\
\text { way in order that they } \\
\text { construct new knowledge in } \\
\text { a collaborative environment } \\
\text { (constructivism) } \\
\text { - Rubrics are provided that } \\
\text { specify the interaction } \\
\text { criteria for students } \\
\text { - The design of the activities } \\
\text { prompts the instructor to be } \\
\text { present, active, and engaged } \\
\text { with the students }\end{array}$ & $\begin{array}{l}\text { - Course Developer } \\
\text { - Instructional } \\
\text { Technologist (to help } \\
\text { select activities and } \\
\text { discussions that create } \\
\text { engagement, } \\
\text { interaction, reflection) }\end{array}$ & $\begin{array}{l}\text { - Discussions } \\
\text { - Synchronous } \\
\text { interactions (Chat, } \\
\text { Whiteboard, etc.) } \\
\text { - Group activities such as } \\
\text { team site building }\end{array}$ \\
\hline $\begin{array}{l}\text { Assessment and } \\
\text { Measurement }\end{array}$ & $\begin{array}{l}\text { - The types of assessments } \\
\text { selected are based on course } \\
\text { materials that are tied } \\
\text { directly to the stated learning } \\
\text { objectives } \\
\text { - There are multiple types of } \\
\text { assessments and they are } \\
\text { weighted such that students } \\
\text { have multiple paths to } \\
\text { success } \\
\text { - Students receive }\end{array}$ & $\begin{array}{l}\text { - Course Developer } \\
\text { - Instructional } \\
\text { Technologist }\end{array}$ & $\begin{array}{l}\text { - Exams } \\
\text { - Written assignments } \\
\text { - Portfolios } \\
\text { - Assessment should } \\
\text { never be exams only }\end{array}$ \\
\hline
\end{tabular}




\begin{tabular}{|c|c|c|c|}
\hline & $\begin{array}{l}\text { personalized feedback from } \\
\text { the instructor } \\
\text { - For written assessments, } \\
\text { rubrics are provided that } \\
\text { clearly specify success } \\
\text { metrics } \\
\text { - Authentic assessment } \\
\text { techniques are incorporated }\end{array}$ & & \\
\hline $\begin{array}{l}\text { Course } \\
\text { Technology }\end{array}$ & $\begin{array}{l}\text { - Tools and media are selected } \\
\text { to support the learning goals } \\
\text { and objectives } \\
\text { - Technology is easily } \\
\text { accessible and current } \\
\text { - Technology encourages } \\
\text { students to be active learners } \\
\text { - Technology selection poses } \\
\text { no undue financial burden on } \\
\text { students (unless absolutely } \\
\text { necessary to the course) }\end{array}$ & - Course Technician & $\begin{array}{l}\text { - Wikis } \\
\text { - Blogs } \\
\text { - Journals } \\
\text { - Videoconferencing }\end{array}$ \\
\hline Accessibility & - Course is ADA compliant & - Course Technician & - Checklist/review \\
\hline
\end{tabular}

Of course, the above course element table can be expanded to include more or less detail, and should be based on the institutional model for online course quality. However, the objective is to have a "specifications" sheet, and preferably a model online "demo" course to which the instructional development team can benchmark their progress.

The question of "standard" or "canned courses" should be addressed here. There are good arguments for and against standardized courses. The scope and depth of standardization is an institutional question, and must be addressed in the context of the course distribution model. With higher volume of enrollments, it can be expected that an institution will have multiple course sections being taught by multiple full time and adjunct instructors. In addition, students will be moving quickly and continuously through courses in the program. It is important to minimize student confusion over language and navigation, as well as be able to preserve the curricular integrity of courses so that course sequences, particularly those involving prerequisites, are carefully managed.

The argument against standardization is typically one of academic freedom, and the negative effects of standardization on creativity and innovation. We would argue that there is a middle point, and achieving it lies within the key involvement of faculty in the online course production and delivery processes. As described earlier, the model at Colorado State University-Global Campus integrates faculty within the Instructional Development organization as key players and decision makers. We recommend utilizing core faculty as lead faculty in the production and delivery of sets of related courses, and empowering them to update and modify their assigned courses, thereby keeping them relevant, "fresh," and reflective of new information and research, and new pedagogical techniques. 


\section{ORGANIZING THE WORKFLOW AND ESTABLISHING DEADLINES}

We propose a fourteen-week phased approach to online course production, as shown in Figure 4. Within each phase occurs various steps and processes, of which we have provided the crucial ones. The information and process steps we have provided must be adapted to the particular institution's framework and policy guidelines, and other steps note mentioned here will emerge as the entire process evolves. This, however, provides a framework for the individualized process to grow into.

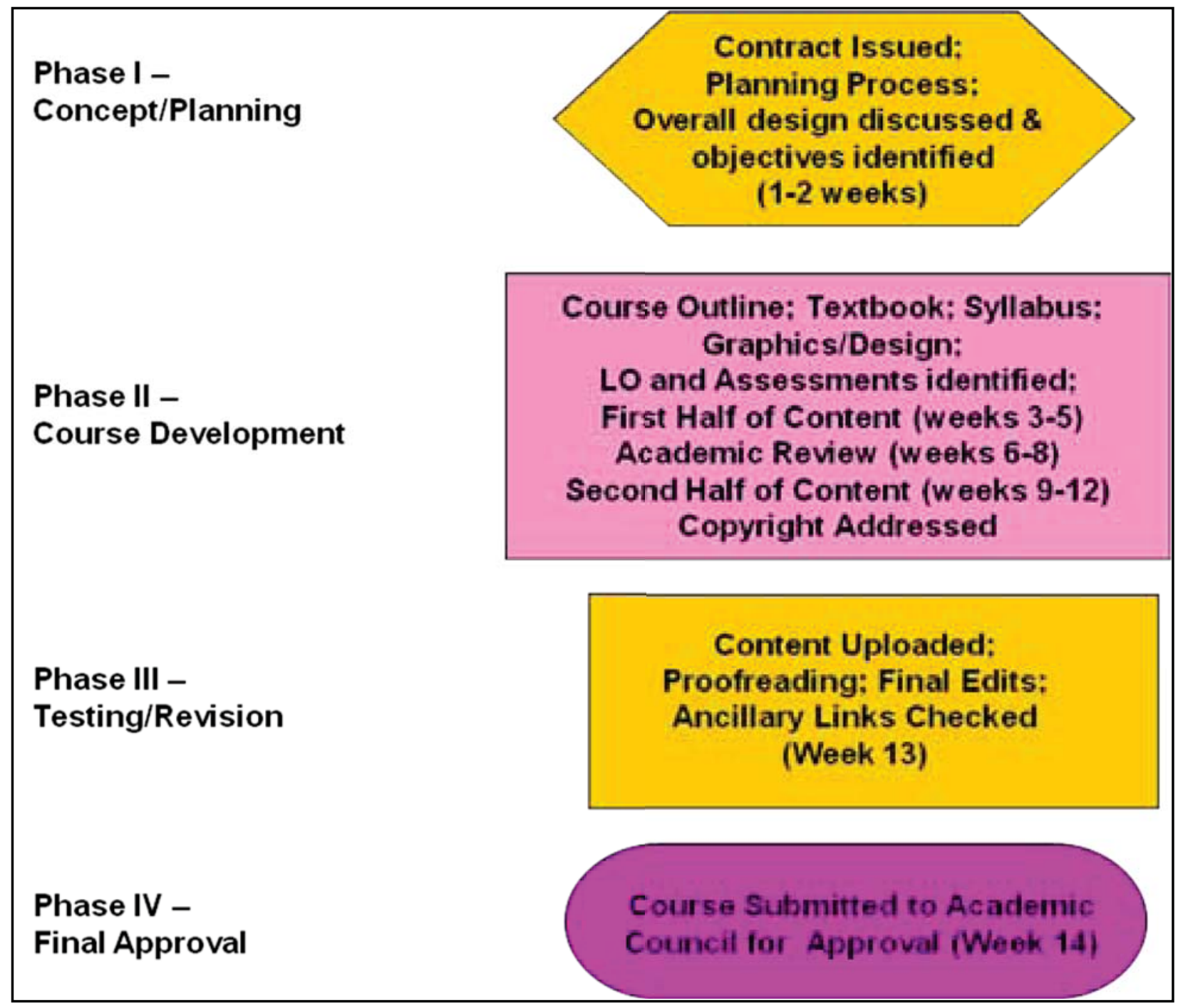

Figure 4: Phases of the Online Course Production Process

\section{A. Phase I - Week 0}

To begin the course development process, a contract is issued and signed by the content experts at an initial orientation meeting. This contract defines expectations for both the subject matter expert(s) and the course development team along with the commitment to follow the 14 week development process as well as provides information regarding payment for the course. This contract is important, as it also defines the institutional policies and any intellectual property issues in the development process. Intellectual property 
is a complex issue, and the institutional general counsel can and should provide input on the development of the legal policy.

Next, the dates for meetings and are established along with a discussion on the resources available for course development such as graphical design, learning object development and copyright support. The core team (Instructional Technologist, Course Technician, and Copyright Librarian) is then introduced to the Course Developer and their roles defined. In our model, the primary "manager" of the workflow process is the Instructional Technologist, and the "co-manager" is the Course Developer. Each needs to be empowered to execute their roles effectively and so "buy-in" of the roles is critical.

At this stage, the team should also make decisions about their communication processes, expectations, and formats. Many Course Developers will be remote, and the group must consider the best technologies for facilitating the work of the team. The new courseshell will then be created in the courseware management system and the subject matter expert(s) will be provided access (ids and passwords). At this point, the initial course syllabus and the assessments already in place will be reviewed for online conversion and the textbook and its resources are examined (for example, does the textbook provide specific graphics that could be used in the course design?).

A course planning document should be provided which is merely a springboard for the subject matter expert to sketch out the course topics and assessments. Institutional policies such as a statement that requires student online participation will be provided for syllabus development and copyright permission forms provided to request usage if guided by the copyright librarian as well as a Teach Act checklist that guides online usage of digital materials. The planning document should be derived from the course design standard, and parallel the language, style, and navigation of the expected final course product.

An excellent resource for this phase is a course developer orientation and a handbook to guide the process. This documentation will serve as reference material for the entire development team. There are numerous excellent examples available freely on the web from various institutions. We also recommend having a "model" course that the faculty can use as a benchmark and emulate in the design and development processes.

In Weeks 1 and 2, the real work begins. Planning commences with discussions of the conceptualization, graphical design, and course planning. After reviewing the learning objectives, the team will discuss any problem areas they see with the content development such as online lab assignments. The development team will then examine the course template for any necessary modifications and then assessment strategy will be reviewed. In this phase, we also recommend involving the Copyright Librarian to begin working with the Course Developer on consideration of materials, and the identification of any potential copyright issues with regard to the initial thinking about the course materials.

Assessment for online courses should never be based upon exams only. In the Active Mastery Learning model, we emphasize multiple paths to success, and active learning techniques. Students will submit several types of assessments which in turn, provide an overall footprint of their work. Online assessment should include online discussions and may also include journaling, case studies, quizzes and exams, just to name a few. The course should incorporate a strategy for building an active community; therefore, an introductory icebreaker exercise may be discussed with different examples provided. 


\section{B. Phase II - Weeks 3-5}

In Phase 2 and by the third week, the team should create the first prototype unit, which includes placeholders for images, interactions, learning games, interactive media objects, etc. This prototype lesson should be checked against the learning model, in this case Active Mastery Learning, and the entire team should agree on the design, the pedagogy, the navigation, the look and feel, and the connection of the unit to the learning goals and objectives.

In this phase, the first draft of syllabus and course schedule should also be submitted by the Course Developer, and should contain the following elements: textbook, supplemental readings list, policies and resources (per syllabus template which will be provided), modularized 8-week course outline with readings, topics, learning goals and objectives, assignment/assessment plan, and discussion questions for each unit. The Syllabus template will also include "static" content (such as contact information, student resources, institutional policies, etc.), and this content should be standardized and maintained by the Instructional Development Unit staff.

Once the course unit prototype and syllabus delineating the weekly goals, objectives and content, is approved, weeks 3-5 are where development should gain momentum. An important part of the process is having milestones and frequently checking progress. Thus, we recommend that the first half of the course content is provided to the team (four complete modules) that contains lecture materials, learning objectives and assessment items. The Copyright Librarian should be involved in this review as well, in order to identify and address and potential copyright issues. This first half of the course should also be submitted for academic review, to ensure that the academic integrity of the curriculum is supported by the course design, pedagogical choices, and technology selection.

\section{Phase II - Weeks 6-8}

Review of the first half of the course content may yield feedback to the development team and adjustments warranted. The Course Developer is consulted for content revisions, while concurrently he or she is working on the last half of the course content to be submitted. This time in the phase allows for catch-up if necessary.

In week nine, the Course Developer will begin submitting content for the rest of the course materials. The Course Technician will make any necessary edits on the first half of the course after review and also work on developing learning objects, loading exams and quizzes, and creating placeholders for the content. By week twelve, all content should be loaded into the course template.

\section{Phase III - Weeks 12-13}

Weeks twelve and thirteen are spent reviewing the second half of the course modules as well as proofreading, testing and revising navigation, electronic activities, etc. The final proofreading and editing should be completed and all hyperlinks and attachments are checked and tested.

\section{E. Phase IV - Week 14}

The final week of the course development phase is allocated for final approvals from the Course Developer, Instructional Technologist, and Course Technician. The Copyright Librarian should also review for any last minute copyright requests. The course is then submitted to the institution's academic council for final approval, if necessary. A date is determined for deployment into the course schedule. A 
post deployment meeting is scheduled for a week or two after the course has been taught. Careful notes should be taken by the instructor throughout the first semester the course is taught.

\section{COURSE MAINTENANCE}

Once courses are entered into a "repository" for the institution, it is important to establish processes and policies to maintain the currency of the courses, as well as update or adjust the course based on feedback from students or faculty teaching the course. Shortly after the course is taught for the first time, the team will review notes kept by the instructor(s) as it was taught. The following items should be discussed and revisions suggested:

- What worked well?

- What were the problem areas?

- Suggestions for improvement?

- Student Feedback?

Revisions will then be made before the next time the course is deployed. A follow-up meeting should occur to discuss revisions after the course is taught again. At this point, the course should be cycled into a normal course update process as determined by the institution which could be 2-3 years or sooner if necessary.

Much of the course maintenance will be driven by the edition cycles of textbook publishers, if traditional textbooks are used. And, Course Developers who update courses will expect a payment for the work. This can become chaotic and costly as course and enrollment volume increases.

There are many possible models for maintenance. Again, we refer to the model of integrating faculty into the organization. In the Core Faculty model, salaried instructors are responsible for selected groups of courses, and they manage the revision process. However, in institutions that primarily utilize adjunct faculty or have shared governance structures where faculty governance and evaluation are dispersed among multiple academic units, the Core Faculty model may not be feasible. However, an appropriate model and process must be established.

\section{CONCLUSIONS}

As Porter [20] states, "An effective curriculum must be well structured, innovative, filled with usable and appropriate course content, and interesting to a variety of people who take each course and work through a series of classes" (p. 75).

The model presented in this paper is one way of achieving such an effective curriculum. With minor adjustments and adaptations, this model should help institutions create a process for organizing online course development into an efficient, coherent, and focused practice. As we continue to learn from our peers, research online learning, and keep learning from our mistakes our model should evolve. This model is currently being implemented at CSU-Global Campus, and formalized research to evaluate the model based on faculty satisfaction, efficiency, quality of design, and student learning outcomes is planned for 2008-2009. Preliminarily, the feedback has been positive and we are looking forward to reporting on the efficacy of the model and practical lessons learned in subsequent reports. 
Online education has forever transformed higher education, and we are learning that quality is really about flexibility and the ability to adapt to the changing demands of learners, the new promises of technology, and the new competitive landscape of higher education. If higher education is to remain competitive, we must refocus and redesign our paradigms, as well as design business processes that integrate with quality assurance models.

\section{REFERENCES}

1. Liu, M.C. Developing Courses for Online Delivery: One Strategy. The Technology Source, 2001. http://technologysource.org/article/developing_courses_for_online delivery.

2. Byun, H.P, K. Hallett \& C. Essex. Supporting Instructors in the Creation of Online Distance Education Courses: Lessons learned. Educational Technology 40(5): 57-60, 2000.

3. Xu, H. \& L. V. Morris. Collaborative Course Development for Online Courses. Innovative Higher Education 32(1): 35-47, 2005.

4. Hawkes, M. \& D. O. Coldeway. An Analysis of Team vs. Faculty-Based Online Course Development: Implications for Instructional Design. The Quarterly Review of Distance Education 3(4): 431-441, 2002.

5. Alvarez, D.M., K. Blair, E. Monske \& A. Wolf. Team Models in Online Course Development: A Unit-specific Approach. Educational Technology and Society 8(3): 176-186, 2005.

6. Knowles, E. \& K. Kalata. A Model for Enhancing Online Course Development. Innovate 4(2): 2007. http://www.innovateonline.info/index.php?view=article\&id=456.

7. The Quality Matters Program is sponsored by MarylandOnline, and was supported in part by the Fund for the Improvement of Postsecondary Education (FIPSE), U.S. Department of Education. http://www.qualitymatters.org.

8. Greenberg, M. A University is Not a Business (and other Fantasies). Educause Review 39(2): 1016, 2004.

9. Allen, E.I. \& J. Seaman. Growing by Degrees: Online Education in the United States, 2005. Needham, MA: The Sloan Consortium, 2005.

10. Palloff, R.M. \& K. Pratt. Lessons from the Cyberspace Classroom: The Realities of Online Teaching. San Francisco, CA: Jossey-Bass, 2001.

11. Chickering, A.W. \& S. C. Ehrman. Implementing the Seven Principles: Technology as a Lever. American Association for Higher Education Bulletin 10: 3-6, 1999.

12. Donovan, M. S., J. D. Bransford \& J. W. Pellegrino. How People Learn: Bridging Research and Practice. Washington, DC: National Academy Press, 1999.

13. Lombardi, M. M. Authentic Learning for the 21st Century: An Overview. Educause Learning Initiative, Diana G. Oblinger (Ed.): 2007. http://www.educause.edu/ir/library/pdf/ELI3009.pdf.

14. Bloom, B. S. Human Characteristics and School Learning. New York: McGraw Hill Book Company, 1976.

15. Kazu, I. Y., H. Kazu \& O. Ozdemir. The Effects of Mastery Learning Model on the Success of the Students who Attended Usage of Basic Information Technologies Course. Educational Technology \& Society 8(4): 233-243, 2005.

16. Oblinger, D. \& B. Hawkins. The Myth about Online Course Development. Educause Review 41(1): 14-15, January/February, 2006.

17. Moore, M. \& G. Kearsley. Distance Education: A Systems View (2nd ed.). Belmont, CA: Thomson Wadsworth, 2005.

18. Peters, O. Distance Teaching and Industrial Production: A Comparative Interpretation in Outline. In D. Sewart, D. Keegan, \& B. Holmberg (eds.), Distance Education: International Perspectives, 95-111. London: CroomHelm/St. Martin's Press, 1988. 
19. Peters, O. Distance Education and Industrial Production: A Comparative Interpretation in Outline (1967). In D. Keegan (ed.), Otto Peters on Distance Education: The Industrialization of Teaching and Learning, 107-127. London: Routledge, 1994.

20. Shelton, K. \& G. Saltsman. Applying the ADDIE Model to Online Instruction. In L. Tomei (Series Ed.) \& L. Tomei (Vol. Ed.), Advances Series: Vol 2._Adapting Information and Communication Technologies for Effective Education, 40-57. Hershey, PA: Idea Group Publishing, 2007.

21. Porter, L. R. Developing an Online Curriculum: Technologies and Techniques. Hershey, PA: Information Science Publishing, 2004.

\section{ABOUT THE AUTHORS}

Maria Puzziferro is currently the Executive Director of Instructional Development for Colorado State University-Global Campus, where she oversees program and online course development, faculty affairs, faculty professional development and support, and library services. Prior to this appointment, Maria served as Associate Dean of Virtual College at Florida Community College at Jacksonville and as Associate Director of the Information Technologies Institute at New York University. Maria has extensive experience planning for academic programs, program development, and distance education operations. She has presented and published extensively on best practices for adjunct faculty recruitment, screening, hiring, and management, as well as best practices for student success and support in distance education programs. Maria received a B.A. from Adelphi University in Political Science; M.A. in Political Science and M.L.S. from St. John's University and; a Ph.D. in Higher Education from New York University.

Kaye Shelton is the Dean of Online Education at Dallas Baptist University whose program now offers twenty-three programs fully online. Teaching online since 1999, Mrs. Shelton holds a certification in Online Teaching and Learning instruction. Her education includes an M.S. in Education emphasizing Online Teaching and Learning and is currently pursuing her PhD in Educational Leadership at University of Nebraska-Lincoln. She has published and presented on developing an online education program, quality online course development and the best methods for teaching online including a recent book entitled An Administrator's Guide to Online Education. She has also served as an advisor and consultant regarding online education programs for several peer institutions. 